\title{
Uji Bioaktivitas Ekstrak Etanol Alga Merah Galaxaura oblongata (Ellis dan Solonder) Lamouroux. Terhadap Beberapa Jenis Bakteri Patogen. (Bioactivity Test of Red Algae Galaxaura oblongata (Ellis and Solonder) Lamouroux Ethanol Extract Against Several Types of Pathogenic Bacteria)
}

\author{
Teresia Panden $n^{\left.1^{*}\right)}$, Johanis Julian Pelealu ${ }^{1)}$, Marina Flora Oktovine Singkoh ${ }^{1)}$ \\ ${ }^{1)}$ Program Studi Biologi FMIPA Unsrat Manado \\ *Email: tres22sia@gmail.com
}

Diterima 5 Juli 2019, diterima untuk dipublikasi 10 Agustus 2019

\begin{abstract}
ABSTRAK
Penelitian ini bertujuan menghitung nilai konsentrasi Minimum Inhibitory Concentration dan Minimum Bactericidal Concentration ekstrak etanol Galaxaura oblongata terhadap bakteri Staphylococcus aureus, MRSA (methicillin-resistant Staphylococcus aureus), dan Salmonella typhi dalam memberikan pengaruh terhadap pertumbuhan bakteri Staphylococcus aureus MRSA (MethicillinResistant Staphylococcus aureus), dan Salmonella typhi. Ekstraksi dilakukan dengan cara maserasi menggunakan pelarut etanol. Pengujian bioaktivitas antibakteri menggunakan metode dilusi cair. Hasil uji bioaktivitas antibakteri dianalisa menggunakan metode Oneway Anova, dilanjutkan dengan Uji Tukey. Uji bioaktivitas antibakteri menunjukkan ekstrak memiliki aktivitas antibakteri. Pada bakteri Staphylococcus aureus konsentrasi ekstrak 90\% ditetapkan sebagai nilai MIC, MRSA pada konsentrasi ekstrak 30\% ditetapkan sebagai nilai MIC, dan pada Salmonella typhi pada konsentrasi ekstrak 30\% ditetapkan sebagai nilai MIC. Data Anova menunjukkan bahwa pertumbuhan koloni tiap konsentrasi ekstrak signifikan artinya tiap konsentrasi berbeda nyata dalam menghambat pertumbuhan bakteri, tetapi nilai $M B C$ belum dapat ditentukan karena masih mengalami pertumbuhan koloni pada hasil pengujian MBC.

Kata kunci : Galaxaura oblongata, bioaktivitas, senyawa kimia, antibakteri.
\end{abstract}

\begin{abstract}
This study aimed to determine the Minimum Inhibitory Concentration and Minimum Bactericidal Concentration of Galaxaura oblongata ethanol extract against Staphylococcus aureus, MRSA (methicillin-resistant Staphylococcus aureus), and Salmonella typhi in influencing the growth of Staphylococcus aureus MRSA (methicillin-resistant Staphylococcus aureus), and Salmonella typhi. Extraction was carried out by maceration using ethanol solvent. The liquid dilution method was used as an antibacterial bioactivity testing. The antibacterial bioactivity test results showed that the extract had antibacterial activity. In Staphylococcus aureus bacteria, concentrations extract of $90 \%$ were determined as MIC values, MRSA of concentrations extract of 30 were determined as MIC values, and in Salmonella typhi at concentrations extract of $30 \%$ set as MIC values. The antibacterial bioactivity test results were analyzed using One Way Anova method, followed by the Tukey Test. Anova's data showed that the growth of colonies in each concentration of extract was significant, meaning that each concentration was significantly different in inhibiting bacterial growth. However, the $M B C$ value could not be determined because it still experienced colony growth in the results of $M B C$ testing.
\end{abstract}

Keywords: Galaxaura oblongata, bioactivity, chemical compound, antibacterial. 


\section{PENDAHULUAN}

Indonesia adalah negara yang sangat kaya akan sumber daya alam salah satunya memiliki berbagai macam tanaman laut yang dapat dimanfaatkan sebagai alternatif obat alami. Oleh karena itu pemanfaatan tanaman laut untuk alternatif obatobatan perlu digali lebih dalam lagi, salah satunya yaitu alga atau ganggang laut (seaweed) yang dapat digunakan sebagai antimikroba alami (Purnamasari et al. 2010).

Alga atau ganggang laut (seaweed) memproduksi senyawasenyawa kimia dari metabolit primer yang dikenal sebagai hidrokoloid. Hidrokoloid telah dimanfaatkan dalam berbagai bahan baku di bidang industri seperti bahan baku pembuatan agar, keraginan, dan alginate. Pemanfaatan alga laut di bidang farmasi selama ini masih terbatas, sedangkan potensi makro alga di Indonesia khususnya di Sulawesi Utara sangat besar untuk dikembangkan sebagai bahan baku obat (Singkoh 2011). Singkoh (2008), telah melakukan riset tentang alga sebagai bahan sediaan farmasetika dan telah dilakukan pada beberapa tempat di Sulawesi Utara diantaranya, Pulau Nain, Tongkaina, Perairan Likupang, dan Malalayang.

Senyawa-senyawa metabolit sekunder yang dihasilkan dengan spektrum luas dari antijamur, antibakteri, antiprotozoal, dan antivirus seperti: senyawa terpen, alkaloid, lektin, holegen, polisakarida, lemak tak jenuh, fenol, karetinoid (Nusaha et al. 2017), Saponin, flavonoid, triterpenoid/steroid (Lutfiyanti et al. 2012), dan florotanin (Varier et al. 2013). Kebanyakan senyawa bioaktif yang terkandung di dalam alga menunjukkan aktivitas antibakteri (Varier et al., 2013).

Alga merah (Rhodophyta) adalah jenis alga yang lebih banyak memiki aktivitas biologi dibandingkan dengan jenis alga lainnya, senyawa-senyawa kimia yang ada pada alga merah didominasi dari famili Rhodomelaceace. Alga merah merupakan sumber pembentuk utama halogenated compunds seperti laurenterol, halomon, dan callicladol. Hologenated compunds memiliki berbagai macam aktivitas seperti, antiinflamasi, sitoksik, insektisidal, antibakteri, antifungi, dan iktiotoksik (Kladi et al. 2003; Cabrita et al. 2010). Alga merah mampu mempertahankan diri dari serangan predator dan berbagai penyakit dengan menghasilkan senyawa metabolit yang aktif (Srikong 2015).

Infeksi dan resistensi bakteri patogen diseluruh dunia saat ini mendapatkan perhatian serius, infeksi dan resistensi bakteri patogen ini menyebabkan tingginya angka kematian yang terjadi pada populasi manusia (Khandasany et al. 2008). Penyakit infeksi yang disebabkan oleh mikroba merupakan masalah kesehatan yang penting ditangani, banyak cara yang dapat digunakan untuk pengobatan berbagai jenis penyakit infeksi salah satunya dengan cara pemberian obat antibiotik (Astuti et al. 2003). Perkembangan ilmu pengetahuan dan teknologi menemukan adanya perubahan pola penyakit dan resistensi kuman penyakit terhadap antibiotik, penggunaan antibiotik yang tidak sesuai menyebabkan mikroorganisme patogen resisten sehingga pengobatan infeksi menjadi tidak efektif lagi (Melliawati 2009). Penemuan antibiotik baru yang belum mengalami resisten terhadap mikroba patogen menjadi salah satu solusi alternatif dalam menangani masalah tersebut. Penelitian ini bertujuan untuk menghitung nilai konsentrasi Minimum Inhibitory Concentration dan nilai konsentrasi Minimum Bactericidal Concentration ekstrak etanol Galaxaura oblongata terhadap bakteri 
Staphylococcus aureus, MRSA (methicillin-resistant Staphylococcus aureus), dan Salmonella typhi dan menguji seri konsentrasi ekstrak etanol Galaxaura oblongata dalam memberikan pengaruh terhadap pertumbuhan bakteri Staphylococcus aureus MRSA (methicillin-resistant Staphylococcus aureus), dan Salmonella typhi.

\section{METODE}

\section{Waktu dan Tempat Penelitian}

Penelitian ini dilaksanakan pada bulan Desember 2018 sampai Maret 2019 di Laboratorium Penelitian Jurusan Farmasi FMIPA UNSRAT, Laboratorium Fitokimia Jurusan Farmasi FMIPA UNSRAT, dan Laboratorium Advenced Jurusan Farmasi FMIPA UNSRAT. Pengambilan sampel di Pantai Atep Oky, Desa Atep Oky, Kecamatan Lembean Timur, Kabupaten Minahasa, Sulawesi Utara, Indonesia.

\section{Pembuatan ekstrak Galaxaura oblongata}

Metode ekstraksi senyawa bioaktif pada Galaxaura oblongata, digunakan dalam penelitian adalah maserasi dengan pelarut etanol $96 \%$. Sampel Galaxaura oblongata yang telah diambil sebanyak 1,5 kg dipotongpotong kemudian digerus, sampel yang sudah digerus kemudian dimasukkan ke dalam toples kaca kemudian direndam dengan pelarut etanol $96 \%$ dengan perbandingan 2:1 selama 5 hari kemudian ditambah remaserasi selama 2 hari agar ekstrak lebih maksimal, kemudian tiap hari dikocok. Kemudian maserat disaring menggunakan kertas fitrat merk Whatman no.1 sehingga diperoleh fitrat, setelah itu fitrat diuapkan menggunakan alat rotary vacuum evaporator atau water bath pada suhu 45ㅇ agar terbentuk ekstrak murni dengan konsentrasi $100 \%$, kemudian disimpan pada suhu $18^{\circ} \mathrm{C}$ untuk mencegah kehilangan senyawa- senyawa yang terkandung pada ekstrak sebelum dilakukan uji fitokimia.

\section{Uji bioaktivitas ekstrak etanol Galaxaura oblongata}

Uji biokatifitas ekstrak etanol Galaxaura oblongata menggunakan metode pengukuran turbiditas dengan menggunakan analisis spektrofotometer untuk menetukan nilai MIC dan metode pour plate untuk menentukan nilai MBC. Uji bioaktivitas dimulai dengan sterilisasi alat yang akan digunakan selama penelitian kemudian dilanjutkan dengan pembuatan media, pembuatan seri konsentrasi uji dan kedua kontrol, suspensi bakteri, dan terakhir penentuan nilai MIC dan MBC.

\section{Isolasi dan inokulasi bakteri pada agar miring}

Mengacu pada penelitian Siregar (2009), bakteri uji diambil menggunakan jarum ose yang steril, kemudian ditanamkan pada media agar miring dengan cara menggores, kemudian diinkubasi dalam inkubator pada suhu $37^{\circ} \mathrm{C}$ selama 24 jam. Perlakuan yang sama dilakukan pada setiap jenis bakteri uji.

\section{Pembuatan seri konsentrasi uji dan kontrol}

Ekstrak etanol Galaxaura oblongata dibuat tiga seri konsentrasi dengan rumus:

Keterangan.

$$
\mathrm{V}_{1} \mathrm{M}_{1}=\mathrm{V}_{2} \mathrm{M}_{2}
$$

$\mathrm{V}_{1}=$ Volume sebelum pengenceran, $\mathrm{M}_{1}=$ Konsentrasi sebelum pengenceran, $\mathrm{V}_{2}=$ Volume setelah pengenceran, $\mathrm{M}_{2}=$ Konsentrasi setelah pengenceran.

Larutan kontrol positif dibuat dengan melarutkan $10 \mathrm{mg}$ chloramphenicol dalam $20 \mathrm{~mL}$ akuades dan untuk kontrol negatif menggunakan akuades. 


\section{Pembuatan suspensi bakteri uji}

Bakteri uji yang telah diinokulasi diambil dengan kawat ose yang steril. Pembuatan suspensi distandarisasi dengan menggunakan standar McFarland 0,5 yang terdiri dari 9,95 $\mathrm{mL}$ larutan $\mathrm{H}_{2} \mathrm{SO}_{4} 1 \%$ dan $0,05 \mathrm{~mL}$ larutan $\mathrm{BaCl} 1,175 \%$ yaitu setara dengan kepadatan bakteri $10^{8}$ $\mathrm{CFU} / \mathrm{mL}$ (Sutton 2011). Suspensi bakteri uji dibuat dengan cara mengambil 4-10 ose bakteri dari media yang telah diinkubasi selama 24 jam pada media NA dimasukkan ke dalam tabung yang berisi $\mathrm{NaCl}$ $0,9 \%$, kemudian dihomogenkan, suspensi bakteri kemudian disetarakan kekeruhannya dengan larutan standar McFarland 0,5. Perlakuan yang sama dilakukan pada setiap jenis bakteri uji.

\section{Penentuan nilai Minimum Inhibotory Concentration (MIC) \\ Uji MIC dilakukan dengan} mengacu pada penelitian Munfaati et al. (2014). Seri konsentrasi ekstrak etanol Galaxaura oblongata yang telah dibuat tiga seri konsentrasi disiapkan. Dua puluh tujuh dari tiga puluh tiga tabung reaksi steril yang berisi $8,8 \mathrm{~mL}$ Nutrient Broth steril masing-masing ditambahkan $1 \mathrm{~mL}$ ekstrak etanaol Galaxaura oblongata dan $200 \mu \mathrm{L}$ kultur bakteri. Pada perlakuan kontrol positif tabung berisi 8,8 $\mathrm{mL} \quad \mathrm{NB}$ ditambahkan $1 \mathrm{~mL}$ antibiotik chloramphenicol dan $200 \mu \mathrm{L}$ kultur bakteri. Pada perlakuan kontrol negatif tabung yang berisi $8,8 \mathrm{~mL} \mathrm{NB}$ ditambahkan $1 \mathrm{~mL}$ akuades dan 200 $\mu \mathrm{L}$ kultur bakteri. Semua tabung divortex agar homogen lalu diambil 2 $\mathrm{mL}$ untuk diukur nilai Optical Density (OD) bakteri dengan menggunakan spektrofotometer $(\lambda 630 \mathrm{~nm})$.

Semua tabung diinkubasi selama 18 jam pada suhu $37^{\circ} \mathrm{C}$. Nilai OD paska inkubasi diukur kembali dengan mengambil $2 \mathrm{~mL}$ untuk diukur nilai OD dengan menggunakan spektrofotometer ( $\lambda 630 \mathrm{~nm}$ ). Jika selisih nilai OD $(\Delta O D)=$ paska inkubasi-pra inkubasi) dengan konsentrasi terendah bernilai negatif, maka ditetapkan sebagai Minimum Inhibitory Concetration (MIC).

\section{Penentuan nilai Minimum Bacterial Concentration (MBC)}

Uji MBC adalah uji lanjutan untuk menentukan konsentrasi terendah atau minimal yang dapat membunuh bakteri secara total pada media tumbuh. Uji MBC menggunakan metode pour plate yang mengacu pada penelitian Munfaati et al. (2014) yaitu dengan cara mencairkan NA kemudian menyiapkan cawan petri steril sebanyak tiga puluh tiga buah. Ekstrak etanol Galaxaura oblongata dari tiga konsentrasi dan kedua kontrol yang berada dalam tabung berisi NB, dituang pada cawan petri sebanyak $1 \mathrm{~mL}$ dan NA sebanyak 20 $\mathrm{mL}$, ditunggu sampai media memadat dan setelah itu diinkubasi pada suhu $37^{\circ} \mathrm{C}$. Hasil inkubasi dapat dilihat dengan ada tidaknya pertumbuhan koloni pada NA. Total koloni bakteri yang tumbuh pada media NA dihitung dengan menggunakan Colony Counter.

\section{Analisis data}

Data hasil penelitian uji MBC (Kuantitatif) dianalisis secara statistika dengan uji one way ANOVA. Apabila terjadi perbedaan yang signifikan dilanjutkan dengan Tukey Test menggunakan SPSS 16.0 for windows dengan taraf kepercayaan 95\%.

\section{HASIL DAN PEMBAHASAN}

Hasil penelitian diperoleh ekstrak etanol Galaxaura oblongata sebanyak 21,5 gram, yang diperoleh dengan metode maserasi mengingat metode ini menguntungkan dalam isolasi bahan alam maupun bahan yang berasal dari laut karena selama proses perendaman terjadi proses pemecahan dinding sel yang disebabkan oleh perbedaan tekanan dalam dan luar sel, sehingga 
metabolit yang terdapat pada bahan akan terlarut pada pelarut yang digunakan. Kristanti et al. (2008) menyatakan pelarut etanol adalah pelarut yang tidak bersifat toksik, dan bersifat universal yang cocok untuk mengekstrak semua golongan senyawa metabolit sekunder. Hasil ekstraksi murni kemudian dibagi-bagi untuk membuat ketiga seri konsentrasi yaitu $30 \%, 60 \%$, dan $90 \%$. Perbedaan seri konsentrasi ini bertujuan untuk melihat seri konsentrasi uji mana yang menunjukkan nilai Minimum Inhibitory Concentration (MIC) dan Minimum Bactericidal Concentration (MBC) terhadap ketiga bakteri yang diujikan.

Uji bioaktivitas ekstrak etanol yang dilakukan adalah untuk mengetahui ada tidaknya bioaktivitas pada ekstrak etanol Galaxaura oblongata yang diujikan pada bakteri Staphylococcus aureus, Salmonella typhi, dan MRSA. Pengujian aktivitas antibakteri ekstrak etanol Galaxaura oblongata terhadap bakteri Staphylococcus aureus, MRSA, dan Salmonella typhi dilakukan dengan metode dilusi cair dengan menentukan nilai Minumum Inhibitory Concentration atau Kadar Hambat Minimal dan Minimum Bactericidal Concentration atau Kadar Bunuh Minimal dengan menggunakan parameter nilai absorbansi tiap seri konsentrasi ekstrak. Pada pengujian MIC ditentukan dengan cara mengukur selisih nilai OD pra dan paska inkubasi dengan rumus OD $(\Delta \mathrm{OD})=$ paska inkubasi-pra inkubasi. Apabila menunjukkan nilai negatif berarti menunjukkan adanya penurunan nilai absorbansi yang artinya terjadinya penurunan jumlah sel mikroba yang telah diinkubasi selama 18 jam, sedangkan apabila nilai $\Delta O D$ bernilai positif berarti tidak terjadi pengurangan jumlah sel, atau masih terjadi peningkatan jumlah sel paska inkubasi (Munfaati et al. 2011).

Berdasarkan penelitian yang telah dilakukan nilai $\triangle O D$ dari ketiga konsentrasi dan ketiga bakteri uji, berbeda-beda dalam menghambat pertumbuhan sel bakteri. Pada bakteri Staphylococcus aureus yang mewakili bakteri gram positif hanya pada konsentrasi $90 \%$ yang mengalami penurunan nilai $\triangle O D$ yaitu sebesar 0,44 , sedangkan pada konsentrasi $30 \%, 60 \%$, dan kontrol negatif tidak mengalami penurunan nilai $\Delta O D$, dengan nilai 0.073 untuk konsentrasi $30 \%$, 0,605 untuk konsentrasi $60 \%$ yang berarti masih mengalami peningkatan pertumbuhan sel bakteri. Pada bakteri Salmonella typhi yang mewakili bakteri Gram negatif penurunan $\triangle O D$ sudah dimulai dari konsentrasi $30 \%$, $60 \%$, dan $90 \%$ sedangkan kontrol negatif yang tidak menunjukkan penurunan nilai $\Delta O D$ dikarenakan aquades tidak memiliki senyawa untuk menghambat pertumbuhan bakteri. Pada bakteri MRSA (methicillin-resistant Staphylococcus aureus) atau bakteri yang resisten terhadap antibiotik dari konsentrasi terkecil sudah mengalami penurunan nilai $\triangle O D$ yaitu pada konsentrasi $30 \%$ dengan nilai $-0,198$, $60 \%-0,13$ dan pada konsentrasi $90 \%$ $-1,036$ yang merupakan nilai tertinggi dari semua nilai $\triangle O D$ sedangkan pada kedua kontrol sama-sama tidak mengalami penurunan nilai $\Delta O D$ (Tabel 1).

Berdasarkan hasil yang diperoleh maka dapat ditetapkan konsentrasi 90\% pada bakteri uji Staphylococcus aureus sebagai Minimum Inhibitory Concentration, pada bakteri uji Salmonella typhi konsentrasi ekstrak $30 \%$ ditetapkan sebagai Minimum Inhibotory Concentration dan pada bakteri uji MRSA (Methicillin-Resistant Staphylococcus aureus) konsentrasi $30 \%$ juga ditetapkan sebagai Minimum Inhibitory Concentration ekstrak etanol Galaxaura oblongata dalam menghambat pertumbuhan sel bakteri. Penggunaan beberapa bakteri uji bertujuan untuk mengetahui ekspektrum senyawa bioaktif pada ekstrak Galaxaura oblongata, apabila menghambat pertumbuhan kedua 
jenis gram bakteri yaitu bakteri Gram positif dan Gram negatif dan bakteri resisten yang berarti tergolong berspektrum luas dalam menghambat pertumbuhan koloni, apabila hanya menghambat salah satu jenis bakteri maka senyawa yang dihasilkan digolongkan berspektrum sempit
(Pelczar et al. 2005). Pengujian lanjut untuk menentukan nilai Minimum Bactericidal Concentration (MBC) untuk mengetahui berapa banyak jumlah koloni yang tumbuh pada media NA paska inkubasi, untuk ditetapkan sebagai nilai MBC.

Tabel 1. Hasil Pengukuran Nilai OD pada Uji MIC Ekstrak Etanol Galaxaura oblongata terhadap bakteri Staphylococcus aureus, MRSA, dan Salmonella typhi.

\begin{tabular}{lcccc}
\hline \multirow{2}{*}{ Bakteri Uji } & Perlakuan & \multicolumn{2}{c}{ Nilai OD } & \multirow{2}{*}{ OD } \\
\cline { 3 - 4 } & & Pra Inkubasi & Pasca Inkubasi \\
\hline Staphylococcus aureus & $30 \%$ & 2,322 & 2,124 & 0,073 \\
& $60 \%$ & 2,337 & 2,207 & 0,605 \\
Kontrol Positif & $90 \%$ & 2,955 & 1,919 & $-0,44$ \\
Kontrol Negatif & & 0,089 & 0,200 & 0,111 \\
MRSA & & 0,109 & 0,433 & 0,324 \\
& $30 \%$ & 2,322 & 2,124 & $-0,198$ \\
& $60 \%$ & 2,337 & 2,207 & $-0,13$ \\
Kontrol Positif & $90 \%$ & 2,955 & 1,919 & $-1,036$ \\
Kontrol Negatif & & 0,109 & 0,254 & 0,145 \\
Salmonella typhi & & 0,112 & 0,340 & 0,228 \\
& $30 \%$ & 2,094 & 2,039 & $-0,055$ \\
& $60 \%$ & 2,341 & 2,356 & $-0,015$ \\
Kontrol Positif & $90 \%$ & 2,945 & 2,251 & $-0,694$ \\
Kontrol Negatif & & 0,104 & 0,195 & 0,091 \\
\hline
\end{tabular}

Hasil dari uji MBC yang telah dilakukan terjadi perbedaan pertumbuhan koloni tiap konsentrasi ekstrak Galaxaura oblongata (Tabel 2). Semakin tinggi konsentrasi ekstrak uji yang digunakan maka semakin kuat pula bioaktivitas yang terdapat pada ekstrak dalam menghambat pertumbuhan bakteri (Pelczar et al. 1998). Namun nilai MBC belum dapat ditentukan dikarenakan konsentrasi ekstrak Galaxaura oblongata yang ditetapkan sebagai nilai MBC tiap bakteri uji dimana masih terdapat koloni bakteri uji yang tumbuh pada media NA setelah diinkubasi selama 18 jam.
Berdasarkan hasil maka dapat diketahui, bahwa aktivitas ekstrak Galaxaura oblongata yang bekerja sebagai antibakteri disebabkan oleh kandungan-kandungan senyawa kimia yang berada dalam ekstrak etanol Galaxaura oblongata, yaitu Flavonoid, Steroid dan Tanin. Flavonoid berfungsi sebagai antibakteri dengan mengikat protein pada bakteri sehingga menghambat aktivitas enzim sehingga proses metabolisme bakteri terganggu dan juga sifat lipofisik flavonoid dapat merusak membran sel bakteri karena membran sel mengandung lipid yang memungkinkan sebagai penyalur melewati membran (Robinson 1995). 
Chusni et al. (2005) melaporkan bahwa Flavonoid juga dapat menghambat metabolisme energi dengan menghambat penggunaan oksigen oleh bak teri.Saponin bekerja sebagai antibakteri dengan mengganggu stabilitas membran sel bakteri sehingga sel menjadi lisis, yang mengakibatkan kerusakan membran sel dan meyebabkan keluarnya komponen-komponen penting dari dalam sel bakteri seperti, asam nukleat dan nukleotida (Ganiswarna 1995). Steroid bekerja sebaga antibakteri dengan merusak membran plasma sel mikroba yang pada akhirnya meyebabkan sitoplasma bocor dan keluar dari sel sehingga sel mati, diduga hal tersebut terjadi karena molekul steroid memiliki gugus nonpolar dan polar sehingga menghasilkan efek yang dapat melarutkan komponen fosfolipid membran plasma (Wiyanto 2010).Tanin memiliki peran dalam aktivitas antibakteri dengan mengikat protein sehingga dinding sel mengalami penghambatan (Simbala 2007). Mekanisme penghambatan tanin dengan cara dinding yang telah lisis yang disebabkan oleh senyawa saponin dan flavonoid, sehingga dengan mudah senyawa tanin dapat masuk pada sel bakteri dan mengkoagulasi protoplasma sel bakteri uji.

Tabel 2. Hasil Uji MBC ekstrak etanol alga merah Galaxaura oblongata terhadap bakteri Staphylococcus aureus, MRSA, dan Salmonella typhi.

\begin{tabular}{ccc}
\hline Perlakuan & $\begin{array}{c}\text { Total koloni rata-rata } \\
\text { (CFU/plate) }\end{array}$ & Rata-rata \pm SD \\
\hline Staphylococcus aureus & 3.009 & $1.003 \pm 36,49$ \\
$30 \%$ & 2.645 & $8.816 \pm 45,08$ \\
$60 \%$ & 1794 & $5.980 \pm 45,92$ \\
$90 \%$ & 0 & 0 \\
Kontrol positif & 2998 & $9.993 \pm 32,50$ \\
Kontrol negatif & 2683 & $8.943 \pm 24,00$ \\
MRSA & 1754 & $5.846 \pm 44,65$ \\
$30 \%$ & 1118 & $3.726 \pm 63,31$ \\
$60 \%$ & 445 & $148 \pm 11,37$ \\
$90 \%$ & 2817 & $9.390 \pm 43,65$ \\
Kontrol positif & & \\
Kontrol negatif & 2808 & $9.360 \pm 52,02$ \\
Salmonella typhi & 2393 & $7.976 \pm 97,28$ \\
$30 \%$ & 1759 & $5.863 \pm 47,64$ \\
$60 \%$ & 6 & $2 \pm .00$ \\
$90 \%$ & 2980 & $9.933 \pm 29,36$ \\
\hline Kontrol positif & & \\
Kontrol negatif & & \\
\hline
\end{tabular}

Hasil dari analisa Oneway ANOVA, pengaruh pemberian seri konsentrasi ekstrak etanol Galaxaura oblongata terhadap bakteri Staphylococcus aureus, MRSA (Methicillin-Resistant Staphylococcus aureus), dan Salmonella typhi menunjukkan nilai signifikan 0.00 $($ sig<0,05) Hal ini menunjukkan bahwa terdapat perbedaan yang signifikan antara seri konsentrasi yang digunakan. Dengan kata lain, pengaruh seri konsentrasi terhadap jumlah koloni yang dihasilkan pada ke tiga bakteri uji berbeda antara satu dengan yang lainnya. Hasil analisis Oneway ANOVA dilanjutkan karena terdapat perbedaan yang signifikan, hasil dianalisis lanjut menggunkan Uji Tukey untuk mengetahui pengaruh 
seri konsentrasi dalam membunuh pertumbuhan bakteri uji. Hasil dari Uji Tukey terhadap jumlah total koloni yang dihasilkan pada bakteri Staphylococcus aureus. Hasil analisis menunjukkan seri konsentrasi berpengaruh terhadap penghambatan pertumbuhan bakteri uji, dimana peningkatan konsentrasi menunjukkan adanya perbedaan aktivitas penghambatan terhadap pertumbuhan bakteri Staphylococcuc aureus.

Hasil Uji Tukey terhadap jumlah total koloni yang dihasilkan oleh bakteri MRSA (Methicillin-Resistant Staphylococcus aureus. Hasil analisis menunjukkan seri konsetrasi $90 \%$ dan $60 \%$ berpengaruh terhadap pertumbuhan jumlah koloni bakteri uji, dimana peningkatan konsentrasi menunjukkan adanya perbedaan aktivitas penghambatan terhadap pertumbuhan bakteri MRSA (Methicillin-Resistant Staphylococcus aureus). Hasil Uji Tukey terhadap jumlah koloni yang dihasilkan oleh bakteri Salmonella typhi Hasil analisis menunjukkan seri konsentrasi berpengaruh terhadap penghambatan pertumbuhan bakteri uji, ditunjukkan dari peningkatan konsentrasi adanya perbedaan aktivitas penghambatan terhadap bakteri Salmonella typhi.

\section{KESIMPULAN}

Nilai konsentrasi Minimum Inhibitory Concentration Ekstrak Etanol Galaxaura oblongata diperoleh konsentrasi $90 \%$, pada bakteri Staphylococcus aureus -0,44, MRSA (Methicillin Resistant Staphylococcus aureus) pada konsentrasi 30\% -0,198, dan Salmonella typhi pada konsentrasi 30\%-0,055. Untuk nilai konsentrasi Minimum Bactericidal Concentration belum dapat ditentukan karena masih terdapat pertumbuhan koloni bakteri tiap konsentrasi ekstrak, dan semakin tinggi konsentrasi ekstrak etanol Galaxaura oblongata maka aktivitas biologi yang dihasilkan semakin kuat dalam menghambat pertumbuhan bakteri Staphylococcus aureus, MRSA, dan Salmonella typhi.

\section{DAFTAR PUSTAKA}

Astuti P, Alam G, Pratiwi SUP, Hertiani T, Wahyuono S (2003) Skrining Senyawa Antifeksi dari Spons yang dikoleksi dari Bunaken, Manado. Jurnal Biota 8 (2): 47-52.

Cabrita MT, Vale C, Rauter AP (2010) Mar Drugs 8(8): 2301-2317.

Chusnie TPT, JL Andrew (2005) Antimicrobial Activity of Flavonoids. Journal International of Antimicrobial Agents 27 (2): 181.

Ganiswarna GS (1995) Farmakologi dan Terapan. Edisi IV. Penerbit UI Press. Jakarta.

Kandhasany M, Arunachalam KD (2008) Evaluation of in Vitro antibacterial property of seaweeds of southeast coast of India.

Kladi M, Vagias C, Roussi V (2013). Phytochem. Rev. 3 (3), 337.

Kristanti AN, NSM Aminah, B Tanjung, Kurniadi (2008) Buku Ajar Fitokimia. Unair Press, Surabaya.

Lutfiyanti R, Ma'ruf WF, Dewi EN (2102) Aktivitas Antijamur Senyawa Bioaktif Ekstrak Gelidium latifolium terhadap Candida albicans. Jurnal Pengelolahan dan Bioteknologi hasil Perikanan 1 (1): 26-33.

Munfaati PN, Evie R, Guntur M (2014) Aktivitas Senyawa Antibakteri Ekstrak Herba.

Melliawati R (2009) Esherichia coli dalam Kehidupan Manusia. Jurnal BioTrend. 4(1).

Nusaha, Muchtaridi (2017) Aktivitas Antimikroba dari Senyawa Bioaktif Rumput Laut atau Mikroalga. Jurnal Farmaka 15 (2): 208-213.

Purnamasari DA, Munadzirah E, Yogiartono RM (2010) Konsentrasi Ekstrak Biji Kakoa Sebagai Material Alam dalam Menghambat Pertumbuhan Streptococcus mutans. Journal PDGI. 14-18. 
Pelczar MJ, Chan ECS (2005) Dasardasar Mikrobiologi 1. Jakarat. Penerbit UI Press, Jakarta.

Pelczar MJ, Chan ECS (1988) Dasardasar Mikrobiologi Jilid 2. Jakarta. Penerbit UI Press, Jakarta.

Robinson $T$ (1995) Kandungan Organik Tumbuhan Tinggi. Edisi 6. ITB Press. Bandung.

Singkoh MFO (2008) Uji Farmasetika pada Alga Laut Gracilaria adulis (S. G. Gmelin) P. C. Silva, Caulerpa racemosa (Forsskal) J. Agardh, Boergesenia forbesii (Harvey) J. Feldmann, Halimeda macroloba Decaisne dari Perairan Pulau Nain Kabupaten Minahasa Utara Sulawesi. [Tesis]. Program Pascasarjana, Universitas Sam Ratulangi Manado.

Singkoh MFO (2011). Aktivitas Antibakteri Ekstrak Alga Laut Caulerparacemosa dari Perairan Pulau Nain. Jurnal Perikanan dan KelautanTropis 7 (3): 123-127.
Simbala HEI (2007) Uji Toksisitas dan Uji Praklinik Areca vestiaria/ Pinang yaki sebagai antifertilitas.

Srikong Watee (2015) Antimicrobial activity of Seaweed Exstrak from Pattani, Southeast coast of Thailand. Food and Applied Bioscience Journal 3 (1): 39-50.

Varier KM, Miltan MC, Arulvasu C, Gajendran B (2013) Evaluation of Antibacterial Properties of Selected Red Seaweeds from Rameshwaram Tamil Nadu India. Journal of Academia and Industrial Research 1 (11): 667670.

Wiyanto DA (2010) Uji Aktivitas Antibakteri Ekstrak Rumput Laut Kappaphyus alvarezii dan Euchema denticullatum Terhadap Bakteri Aeromonas hydrophila dan Vibrio harveyii. Jurnal Kelautan 2 (1): 13. 